\title{
Empowering Organizational Culture to InCrease Senior High SCHOOl Principal's Performance
}

\author{
Sutji Harijanto \\ Universitas Pakuan, Bogor, Indonesia \\ E-mail: sutjihar@unpak.ac.id
}

\begin{abstract}
This study aims to explore the empowerment of organizational culture in increasing the senior high school Principal's performance. This research used a survey method with a causal approach. The affordable population in this study were 146 heads of public and private high schools in East Jakarta. The sampling technique used is simple random sampling. The data were collected using a questionnaire. The data analysis technique used descriptive analysis and inferential analysis (path analysis). The result shows that the senior high school Principal's performance can be increased by empowering organizational culture. It also shows that the senior high school Principal's performance strengthens the notion that the higher score of the independent variables of organizational culture, the higher score of the senior high school Principal's performance serving as the dependent variable. Strengthening organizational culture will improve senior high school Principal's performance. Finally, the senior high school Principal's performance was examined at one point in time. The quality of the principal's performance will increase if organizational culture also increases.
\end{abstract}

Keywords: Senior High School Principal; Performance; Organizational Culture Empowerment

\section{INTRODUCTION}

According to the 2007 Human Development Index published by the United Nations Development Program, Indonesia's human resource quality is ranked 107 out of 177 countries, more precisely Indonesia's rank below Thailand, Singapore and the Philippines. While Malaysia is ranked 63, which means the education system in Malaysia to develop the quality of human resources better than Indonesia. Whereas in the 1970s Malaysians learned a lot to Indonesia, even the Malaysian government brought in subjects of Mathematics and Natural Science to teach schools in Malaysia.

Particularly on the performance of the headmaster of Senior High School in East Jakarta City which is the target of research, this region is divided into 10 districts and has a high school population of 146 schools, which can accommodate students as many as 57,013 children. The performance of senior high school principal in East Jakarta in 2008 can be stated in two aspects, namely: (1) equity of education, and (2) improvement of quality. In the educator sector of 4,690 teachers have been identified as many as $61.87 \%$ are included in the category of decent teaching, and $38.13 \%$ into the category not worth teaching.

The above facts are some indications of the low performance of senior high school principals in East Jakarta.
The low performance, not apart from low student input, low quality of teaching and learning process, low teacher qualification, low work motivation, work climate, principal leadership style is not suitable to influence subordinates, less precisely the organizational culture applied by the citizens of the school and others. If this is not addressed, it can create distortions that will hamper the development of education in East Jakarta, which is difficult to compete in national and international forums.

The performance of senior high school principal in East Jakarta was conducted by a team consisting of the Head of Sub Department of Secondary Education as Team Leader, Head of Senior High School Section and High School Supervisor Coordinator. The purpose of the assessment is to: (1) know the principal's performance (2) as an ingredient for formulating school counselling policies and programs (3) references for the promotion of the principal's position.

The focus of this research is on how organizational culture can improve principals' performance. Is there an influence of a particular organizational culture indicator that can improve the performance of the principal? 


\section{LITERATURE REVIEW}

\section{A. Performance}

Understanding performance by experts, on the one interpreted as performance and on the other hand is understood as work performance. Similarly, definitions of performance include different missions. But in principle, the performance leads to an effort to achieve better work performance. Robbins and Coulter (2007: 254) stated that success in doing a job is largely determined by performance. Meanwhile, Hersey, Blanchard, and Johnson (1996: 92-93) argued that performance is the result of an activity or work. While Bernardin and Russell in Ruky's book (2006: 15) put forward performance is the record of the outcome produced on a specified time function. Referring to the definition contained three aspects that need to be understood by every leader of an organization and (2) clarity of results expected by the organization, and (3) the time required to complete the work. In line with the above opinion, Handoko (2000: 11) argued that performance as a process by which the organization evaluates or assesses employee performance

Furthermore, Bowin and Harvey (1996: 140) stated that Performance may be defined as the accomplishment of an employee or manager assigned duties and the outcomes produced on a job function or activity during the specified period. The definition contained the meaning that performance is associated with achievement factors because it is associated with seriousness in the work. Performance words also refer to the results of work in the completion of the work, handling or execution of a task. Bates and Hoeton, quoted by Amstrong and Baron (1998: 15) suggested that performance as a result of work or behaviour.

Thus, the term performance will lead to two things, namely the process and the work achieved. Performance is an action of a process involving various components of activity. Performance is not only seen as a result that occurs at a certain point in time. While Robbins and Coulter (2007: 231) stated the performance is a benchmark of success in doing something work.

Another opinion was expressed by Hodgetts \& Kuratko (1988: 438) that performance is concerned with how well a person does his job. Associated with an individual's role in the organization, performance is a set of individual behaviours or activities that match the expectations or desires of the organization in which he works (Hugh and Fieldman 1986: 24).

Whereas, according to a behavioural approach in management, performance is the quantity or quality of something produced or services provided by a person doing the work (Luthans, 1995: 352). Referring to these limits can be stated that performance is the result, both quantity, and quality, which one achieves in carrying out the tasks that are his responsibility. Another opinion expressed by Newstrom and Davis (2002: 212-213) stating that good performance will be generated by satisfied employees or employees within the organization. A satisfied employee or employee will make a supportive effort to do his job well. In the context of the definition contained the meaning that the performance is related to job satisfaction so that if an employee in an organization satisfied with the results of his work, the welfare provided by the organization and its products used by the people, and received praise from the leadership, it will result in a performance that.

Furthermore, Hersey \& Blanchard (1993: 8) stated to assess the performance of principals it is necessary to know in advance the main skills that must be owned, roles, and duties. The principal skills of an administrative leader are grouped into three parts: conceptual, humanitarian and technical. Conceptual skills are the ability to know the wisdom of the organization as a whole. Humanity skills are the ability to work in groups or coordinate groups, whereas technical skills are the ability to use methods, processes, procedures, and techniques that are usually associated with tools. This skill is important for middle or lower-level leaders.

Meanwhile, Knezevich (1984: 337) stated that the role that the principal runs in charge of the school is as: (1) the communication agency between the teacher and the school system, between the community and the school, between the students and the learning program; (2) leaders in learning activities. The principal must understand the curriculum and its impact on the learning facilities, understand the learning program and its impact on financing, find out the necessary learning materials, and seek organizing and utilization of student learning time; (3) a catalyst that can motivate the growth of staff professionalism. Encourage students to achieve high learning outcomes and get schools to achieve high educational achievements; (4) managers of various sources to achieve quality learning. It is responsible for protecting, using as well as possible and checking the use of such resources for the benefit of the learning process; (5) security guards, control and enforce discipline to maintain smooth learning; (6) serves as a student advisor fairly, objectively, appreciates the views of others and can minimize conflict. Meanwhile, Hayness (1984: 134-135) stated that in evaluating the behaviour of a person associated with its performance, then that needs to be considered is the method of work, work procedures, and work habits. Thus, the behaviours that can be evaluated are (1) leadership; (2) planning; (3) organizing; (4) the determination of priority; (5) delegation; (6) control; (7) problem solving; (8) decision making; (9) direct communication; (10) written communication; (11) the ability of administration (12) ability to connect with others; (13) safety of work; (14) cleanliness; (15) timeliness; (16) presence.

Thus, the performance of principals implies conceptual skills, humanitarian skills, and technical skills. The principal's performance is also linked to his role as a school liaison agent with teachers, students, and the community; leader of learning activities; catalyst to achieve school performance and renewal; school order keeper; and managers of the various resources that exist in the school. The performance of principals is also assessed through working methods, work procedures and work habits.

Based on the above descriptions, the definition of performance in this study is the performance performed by 
the principal in the context of the execution of tasks and functions to achieve organizational goals, with indicators: plan work programs, able to complete tasks well, responsiveness to complaints and achievements, cooperation, administrative management, and evaluation of work programs that have been implemented.

\section{B. Organizational Culture}

Bounds cited by Nasution (2001: 179) suggested that culture contains many key aspects, namely: (1) culture is a social construction of cultural elements, such as values, beliefs, and understanding, shared by all members of the group, 2) culture provides demands for its members in understanding an event, (3) culture contains customs or traditions, (4) in a culture, patterns of values, beliefs, expectations, understanding, and behaviour arise and develop over time, (5) culture directs behaviour, customs or traditions as a glue that unifies an organization and ensures that its members behave following the norm, and (6) the culture of each organization is unique. Referring to these concepts, the notion of culture is a complex whole that deals with patterns of behaviour and beliefs covering the values, knowledge, norms, morals, expectations, laws and other abilities and habits adopted repeatedly by humans as a member of society. Furthermore, Bounds defines the organizational culture as "the embodiment of the values and traditions underlying the organization, as seen in how employees behave, employees' expectations of the organization and vice versa, and what is reasonable in terms of how employees perform their work.

Meanwhile, Robbins and Judge (2007: 585) defined the organizational culture as follows: "organizational culture refers to a system of shared meaning held by members that distinguish the organization from other organization". This means that organizational culture refers to a system of shared meanings formed by its members as well as organizational differentiation. Thus, every organization should not have the same culture. Each organization has an organizational culture that is characteristic, and at the same time a differentiator with other organizations.

Organizational culture greatly affects the working atmosphere in the organization. Organizational culture is the daily manifestation of the values and traditions underlying the organization seen how to behave, the expectations of employees to the organization and vice versa, and what is considered reasonable in terms of how employees perform their work.

Meanwhile, according to Luthans (1995: 74) organizational culture is "a pattern of basic assumption invented, discovered, or developed by a given group as it learns to cope with as problems of external adaption and internal integration that has worked well enough to be considered valuable and, therefore, to be taught to new members as the correct way to perceive, think, and feed concerning those problems". From this definition, it seems that the real organizational culture grows because it is created and developed by individuals working in an organization, and accepted as values that must be maintained and passed on to each new member. These values are used as guidelines for each member as long as they are in the organization's environment and can be regarded as a distinctive feature that distinguishes an organization from other organizations.

Furthermore, Jones (2001: 130-131) argued: organizational culture is the set of shared values and norms that control the organization members interactions with each other and with people outside the organization. Values are the general criteria, standards, or guides principles that are used as desirable or undesirable. Norms are standards or styles of behaviour that is acceptable or typical for a group of people. In definition, it is meant that organizational culture is a set of widespread values and norms that can control the interaction between members of the organization and members of the organization with people outside the organization. Values are general standards of principles that are considered good and not well done. While the norm is a standard of behaviour that may or should not be done and which members of the organization should not do.

Meanwhile, Gibson, Donelly, and Ivancevich (2006: 31) stated that organizational culture is what the employees perceive and how this perception creates a pattern of beliefs, values, and expectations. Thus, it implies that what the employee understands and how that perception creates a pattern of beliefs.

Later in its development, Kreitner and Kinicki (2008: 42) stated that organizational culture is the set of shared, taken for granted implicit assumptions that a group holds and determines how it perceives, thinks about, and reacts to its various environments. Where in the statement has the meaning of organizational culture is a form of an assumption that is owned, received implicitly by the group and determine how the group feel, think and react to its diverse environment. As Schein (2004: 17) put it, the organization is a pattern of a set of basic assumptions used by its members in solving both internally and externally successful and legitimate internal adaptation problems and then taught to new members as a proper way of feeling, seeing and analyzing problems.

Meanwhile, Robbins (1994: 262) stated there are five functions of organizational culture, namely: (1) Culture has a role of setting boundaries, meaning that cultures create a clear distinction between one organization and another. (2) Culture brings a sense of identity to its members. (3) Culture facilitates the birth of commitment to something wider than individual interests. (4) Culture enhances the stability of the social system. (5) Culture is a social glue that helps to unify the organization by providing the right standards for what employees should say and do.

Organizational culture will affect performance and job satisfaction when viewed from the dimensions of management, members of groups and members individually. That whole perception becomes an organizational culture. Perceptions that support or not support this will affect employee performance and satisfaction. Employee performance or satisfaction will increase as the organizational culture improves. 
From a group member point of view, organizational culture will provide direction in finding ways to achieve organizational goals. In this case, organizational culture can have a positive or negative influence depending on the compatibility or compatibility of the culture with the development of the internal and external environment. Further, Robbins states that perceptions that support or not support affect employee performance and satisfaction with a greater impact on stronger cultures. Thus, the better the employee's perception of organizational culture and its application, the better the performance and job satisfaction of employees.

Based on the results of the above study and analysis, what is meant by the organizational culture in this study is a guideline adopted by the organization covering the values, norms, principles and rules applicable within the organization to determine how the members of the organization act with indicators: initiate decision-making processes, tolerate actions and conflicts, guide subordinates, supervise, cooperate, reward, seek direction and support from superiors.

\section{METHODOLOGY}

This research used a survey method with a causal approach. This study examined or analyzed the interrelationship between research variables, and measure the influence of one variable on other variables. The variables studied were two types, namely: (1) Organizational Culture (X), and (2) Performance of School Principal (Y).

The target population in this study was all senior high school principals in East Jakarta. The affordable population in this study were 146 heads of public and private high schools in East Jakarta. The sampling technique used was Simple Random Sampling is simple random sampling. Using this technique obtained 60 samples from an affordable population of 146 .

The data were collected using a questionnaire. The data analysis technique used descriptive analysis and inferential analysis (path analysis). Descriptive analysis was used to view the description of the data from each of the research variables shown through the mean, median, mode, frequency distribution list, and histogram. Thereafter, a large direct effect of exogenous variables on endogenous variables was calculated. The magnitude of the influence is reflected in the magnitude of the path coefficient.

\section{RESULTS AND DISCUSSION}

The influence of Organizational Culture $(\mathrm{X})$ on the Performance of School Principal (Y). The hypothesis states that Organizational Culture (X1) has a direct effect on Performance (X4). Based on the calculation shows the coefficient of the path $\mathrm{P} 41=0.138$, and it turns out that the obtained path coefficient is above 0.05 so the path coefficient is very meaningful. It shows Organizational Culture has a positive and significant impact on Performance. Thus, the third proposed hypothesis which states Organizational Culture (X1) has a direct effect on
Performance (X4), is acceptable. To know the significance of Organizational Culture (X1) on Performance (X4), the significance test with a t-test is done. The path coefficient is significant when the value is t-count $>$ t-table. Result of $t$ test calculation is big $\mathrm{t}$-count $=2.14$ while $\mathrm{t}$-table $=167$ at $\alpha$ $=57$ and $\alpha=0,05$, so t-count $>\mathrm{t}$-table, or $2.14>1.67$. This showed that the influence of Organizational Culture (X1) on Performance (X4) is significant. Thus, it can be stated Organizational Culture is instrumental in improving the Performance of the School Principal.

After the hypothesis test is done, then the next step is to calculate the magnitude of direct and indirect effects between research variables. The following table summarizes the results of the direct and indirect effects of Organizational Culture (X).

Concerning the results of the research hypothesis testing, several points need to be discussed further. The result of the research shows that there is a direct influence of Organization Culture on Performance. This is in line with the theoretical models expressed by Colquit, Wesson, and LePine (2009: 37) and supported by Robbins (1994: 265) statement that organizational culture will influence performance and job satisfaction when viewed from the dimensions of management, group members and members individually. The great coefficient of the path between organizational culture to performance equal to $\mathrm{p} 31=0.458$. The effect of organizational culture on performance is 0.2097 .

Organizational culture affects Performance. The coefficient of the path between Organization Culture to Performance is $\mathrm{p} 41=0.138$. The big direct influence of organizational culture on performance is equal to 0,019 . However, these results show little effect, but these results prove that organizational culture can improve performance. Culture greatly affects the working atmosphere within the organization. Organizational culture is the everyday embodiment of the values and traditions underlying the organization that will show how employees behave, employee expectations of the organization and vice versa, and what is considered fair in terms of how employees perform their work. The findings of this research support Mondy and Noe's statement that there is the influence of organizational culture or corporate culture on employee performance (a firm's culture has an impact on employee job satisfaction as well as on the level and quality of employee performance). Furthermore, Robbins (1994: 24) stated that an organizational culture is an important tool in improving organizational performance.

\section{CONCLUSIONS}

Based on the analysis of the research results can be submitted as follows: (1) Organizational culture has a direct effect on the Performance of the School Principal of $1.90 \%$ with a path coefficient of 0.138 . So Organizational Culture proved to have a direct effect on Performance. In other words, the stronger the Organizational Culture, the higher the Performance of the School Principal. (2) Organizational Culture indirectly affects the Performance of the School 
Principal by $20.76 \%$. So Organizational Culture proved to indirectly influence Principal Performance. In other words, the stronger the Organizational Culture, the more Performance increases, so the better the Performance of the School Principal.

The implication of organizational culture into the performance of the school principal: (1) It needs to improve excellent educational services to customers (students, parents/community). To achieve these targets can be done through the training/workshop for school residents to codify aspects of the discipline, the accuracy of loyalty, involvement, and partisanship in the organization. In carrying out the work, members of the organization should always reflect on the motto, for example: "quality products and guaranteed to compete", as a work culture in providing services to customers. (2) Need to cultivate the teachers to open the website or the internet on their computers, to find information about science and technology related to educational services, before doing daily routine work. This conditioning can be achieved through a regular meeting strategy with the teaching council. (3) It is necessary to reregulate the implementation and promotion of performancebased principals. The promotion of the principal needs a rigorous selection concerning psychological history (profile psychological profile) and career history (track record). Headmasters who have high career record with high achievement are given high weight who have the opportunity to be elected and promoted to the headmaster for period II, or promoted to other high school principals who have the superior category, or promoted relevant to be structural officials at Dinas Pendidikan.

\section{REFERENCES}

Amstrong, Michael and Baron, Angela. (1998). Performance Management. London: Institute of Personnel and Development.

Bowin, Robert Bruce, and Harvey, D. (1996). Human Resource Management. New York: McGraw-Hill.

Colquit, LePine., Wesson, Calquit., and LePine, Wesson. (2009). Organizational Behavior. Boston: McGrawHill.

Gibson, James L., Donelly, James H. Jr., and Ivancevich, John M. (2006). Organizations: Behavior, Structure, Processes. New York: McGraw-Hill.

Handoko. (2000). Manajemen Personalia dan Sumber daya Manusia. Jakarta: PT. Gramedia.

Hayness, Marion E. (1984). Managing Performance: A Comprehensive Guide to Effective supervision. California: Lifetime learning Publications.

Hersey Paul, Blanchard, Kenneth., and Johnson, Dewey E. (1996). Managing Organizational Behavior Utilizing Human Resources. New Jersey: Prentice Hall, Inc.

Hersey, Paul and Blanchard, Kenneth H. (1993). Management of Organisasi Behavior: Utilizing Human Resources. New Jersey: Prentice-Hall International, Inc.
Hodgetts, Richard M. and Kuratko, Donald F. (1988). Management. San Diego: Harcourt Brace Jovanovich Publishers.

Hugh, Arnold J. and Fieldman, Daniel C. (1986). Organizational Behavior. New York: McGraw-Hill Book Company.

Jones, Gareth R. (2001). Organizational Behavior. Third Edition. United States of America Wesley: Longman Publishing Company. Inc.

Knezevich, Stephen J. (1984). Administration of Public Education: A Source Book for the Leadership and Management of Educational Institution. New York: Harper Collins Publishers, Inc.

Kreitner, Robert dan Kinicki, Angelo. (2008). Organizational Behavior. New York: McGraw-Hill.

Luthans, Fred. (1995). Organizational Behavior. New York: McGraw-Hill, Inc.

Nasution, M.N. (2001). Manajemen Mutu Terpadu. Jakarta: Ghalia Indonesia.

Newstrom, John W. and Davis, Keith. (2002). Organizational Behavior: Human Behavior at Work. New York: McGraw-Hill.

Robbins, Stephen P. (1994). Teori Organisasi, Struktur, Desain dan Aplikasi. Terjemahan Yusuf Udaya. Edisi 3. Jakarta: Penerbit Arcan.

Robbins, Stephen P., and Coulter, Mary. (2007). Manajemen, Jilid 2. Terjemahan Harry Slamet \& Ernawati Lestari. Jakarta: PT. Indeks.

Robbins, Stephen P., and Judge, Timothy A. (2007). Organizational Behavior. New Jersey: McGrawHill.

Ruky, Achmad S. (2006). Performance Management System. Jakarta: PT Gramedia Pustaka Utama.

Schein, Edgar H. (2004). Organizational Culture and Leadership. San Francisco: Jossey-Bassa Publisher. 